\title{
印刷インキの最近の動向
}

市川家康

大蔵省印刷局（東京都港区赤坂葵町 2)

\section{Printing Ink}

Recent Trends in Printing Inks

\section{Ieyasu Ichik AwA}

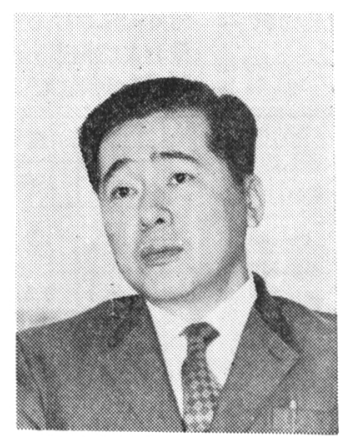

Government Printing Bureau, Ministry of Finance (Akasaka Aoi-cho-2, Minato-ku Tokyo)

\section{1 は じめに}

印刷技術は過去 200 年の間アマニ油ワニスとともに進 歩してきたともいえる。その乾燥工程は重合によってワ 二ス分子を低分子量から高分子量へ変化することであっ た。この化学反応を早めるためにたとえば金属セッケン のような乾燥剤を触媒として用いたり, またはキリ油の ようなより乾燥速度の速い乾性油を用いることが考えら れた。しかし, 化学反応の形式に本質的な革命が起きた わけではない。

さらに, 官能性の概念がその後のワニスの発達を支配 してきたと考えても誤りではなかろら。たとえば 4 官能 性の分子からの反応速度は 3 官能性のものよりも速く, 橋力ケ構造をとりやすく乾燥も速い。

たしかにグーテンベルグ以来, 印刷インキの乾燥方式 は基本的にはあまり変わったことがない。平，凸版の分 野では相変らずアマニ油のような乾性油の乾燥, あるい はある種の鉣物油の浸透を原理とした乾燥であり, この 種の乾燥には, 液体が固化するまでかなりの時間がかか る。

技術面でまったく別種の硬化機構の実現をみたのは, 1940 年代のことで, ヒートセットインキ, スチームセ ットインキがその要望に応えて登場した。

ヒートセットインキはロジン変性樹脂を沸点 250 $300^{\circ} \mathrm{C}$ の石油系溶剤に溶解したものをビヒクルとしたイ ンキで, 印刷直後ガスバーナーその他の乾燥装置上で溶 鼡を強制排出する仕組みにより, きわめて短時閒内で乾 燥するもので, 当時凸版印刷の革命とみられたわけであ る。スチームセットインキは水と相溶性のある溶剂に水 に不溶の酸価の大きい合成樹脂（たとえばロジン・マレ イン酸付加物）を溶解したものをビヒクルとするもの で，印刷後蒸気または霧などを吹きかけて水分を与える と樹脂が顔料を包んで沈殿し, 水分に薄められた溶剂は 紙中に浸透して乾燥インキ皮膜を作る。セットの速度は
ヒートセットに匹敵するが，湿度に不安定な欠点を有し ている。

ヒートセットにしろ，スチームセットにしろ膨大な乾 燥付属設備を要することおよびわが国の気候条件などの ため，国内では二，三の大会社を除いては一般に普及す る余地がなかった。

その後フレキソ印刷や, 巻取紙によるオフセット印刷 の爆発的な生長があり，インキ技術者に対して刺激的な 挑戦状をつきつけているものといえよう。

長い間印刷技術者が描いた印刷インキに対する理想像 は次のようなものであろらと思われる。

「印刷機の上では絶対に乾かないで，印刷後はただち に乾いてしまうような印刷インキ」

この願いが熱烈であり正直であるほど現実のインキは その状態とは程遠いところにあるといらのが為らない共 通の認識であろう。

印刷技術の技術的進歩に伴って，印刷速度は上昇の一 途をたどる。機械的には現在以上に高速化することは可 能であるが，たとえば凸版印刷ではこれ以上スピードア ップすれば印刷室全体がインキのミストだらけになって しまらだろらし，またオフセットインキは高速化すれば するほど, 紙粉, 紙ムケによるトラブルが発生し, 湿し 水との関係もあって印刷インキ技術上大きな制約をこう むることは必至である。また，被印刷材が紙ばかりでな く, プラスチック，金属フォイル，七ロ八ンなどとなれ ば，印刷面への吸収が悪く，接着性にも大きな影響を及 ぼすであろらから，インキ配合，乾燥技術などにも多く の問題点が残っている。

これらの困難な技術が未解決の状態にありながら，依 然として基本的な問題として残されているのは上の「イ ンキの理想像」にどのよらにして肉迫しらるかといらこ と, いいかえれば印刷直後のインキの急速乾燥技術であ ると言い切って差支えなかろら。

最近はとくにこのような事情を強く反映して, 大気污 
染の公害問題なども合わせ考え従来のタイプとは違った 考え方に基づいたインキ, 乾燥手段も熱以外のエネルギ 一手段, すなわち, マイク口波, 赤外線, 紫外線などの 電磁波や電子線を応用する方向が検討されており, 明日 への問題解決に対してポテンシャルを秘めているように 思われる。

\section{2 熱反応型インキまたは無溶剂型インキ}

従来のヒ一ト七ットタイプの平版, 凸版インキは顔 料, 樹脂, 溶剤の 3 主要成分から成り立っておうり, 印刷 機の機構上，低沸点溶剂は印刷機上で乾いてしまって安 定性が覀いので沸点 $250 \sim 300^{\circ} \mathrm{C}$ の石油系溶剤が用いら れており，場合によってはアマニ油を加えることもあ る。

したがって印刷後, これを揮発するためには高温の乾 燥装置（ガスフレーム, 高速熱風) を必要とするし, 最 近の $250 \sim 350 \mathrm{~m} / \mathrm{min}$ というような高速度印刷になると 乾燥時間も $1 \mathrm{sec}$ 以内を要求される。溶剤の強制排出に 伴ってアフターバーナーや溶剂回収装置を取り付ける必 要があり, 経済的な負担, 火災の危険, 人体に対する有 害性も問題である。一方製品のできばえ，耐摩摖性，耐 水, 耐熱性などそのほか多くの性質について従来のビヒ クルの限界を越えるようなものが要求される傾向が高 まっており,その要求に応えるのは並々のことではない。

したがってより強いインキ皮膜を得るために，単純な 溶剂蒸発ではなく, 何らかの化学反忘を利用して, 液体 ビヒクルを固体に転換するような工夫が必要である。

熱反応型インキ1) はこれに応えて作られたもので，プ レポリマー, 橋力ケ樹脂, 特殊な反応触媒を加えたも ので, 加熱されると触媒が有効に働き出して非常に急速 に反応し皮膜が固化することを利用するものである。

現在開発されているものにアミノアルキド樹脂があ り，あるいは熱硬化性アクリル樹脂などの応用も考えら れる。この型のインキのセットと乾燥は二段に分けて行 なわれる。まず最初に溶剤が除去され，ついで付着した インキ皮膜を一定時間高温にさらしてキュアリングさせ る。つまり二つの樹脂の重合を促進してまったく新しい 高分子化合物の皮膜が生成する。キュアリングの温度は 高いもので, $230 \pm 15^{\circ} \mathrm{C}$, 低いもので $150 \pm 15^{\circ} \mathrm{C}$, 時間も $0.5 \sim 1.5 \mathrm{sec}$ 程度である。あまり温度が高過ぎるとイン キの表面で溶剤の蒸発と同時に重縮合反応が起こって表 面に「あばた」ができやすいし，低過ぎるとアフタータ ックを残す。

熱反応によってビヒクルから縮合生成物やホルムアル デヒドなどの分解生成物が放出される欠点もあるが, 通 常のヒートセットタイプに比べて放出物は著しく減少す るものとみられる。しかも従来の乾燥装置をそのまま利 用できるといら強みもある。
また, 従来型インキと熱反応型インキの中間的性格を もつインキも考えられる。これを部分触媒型インキと呼 んでおこう。この場合ビヒクルは常に 3 種類の樹脂から 成り立っている。その一つは溶剤の蒸発によって乾燥す る従来の樹脂で他は二つの重合性樹脂と少量の触媒と三 つの樹脂に共通の溶剤から成り立っている。

このインキは印刷する直前に触媒を加える必要がない ので，従来のインキとまったく同じように取り扱うこと ができる。操作上とくに異なった点はない。 $110^{\circ} \mathrm{C}$ 以上 に保った一段のオーブンを出れば印刷物はタックのない 状態で取り出せる。ビヒクル中の重合性樹脂の部分は乾 燥工程中に充分に重合はしないが乾燥皮膜にタックが残 るほどではない。その後も重合性樹脂の分子は触媒に よって徐々に重合し $24 \sim 96 \mathrm{hr}$ かかって完全便化が 完了し, 望ましい皮膜の性質が得られる。このインキは 従来の蒸発型インキと熱反応型インキの折哀されたもの であるから，得られるインキの皮膜もそれに対応したも ので, ほとんどのインキは従来のインキよりすぐれて いる。また，今までの普通の乾燥装置を用いることもで きる。熱反応型インキはきわめて不安定で印刷後いくら か残ったインキは捨てなければならないが，部分触媒型 インキの場合は貯蔵が可能である。また従来型のインキ よりも生成皮膜の物理的, 化学的抵抗力が大きいのが長 所である。

一般に低温硬化の方が印刷技術上からは好ましいが， 重合反応に必要な温度が低いと, 貯蔵中にゲル化し不安 定となりやすいから実際上はきわめて困難とは思われる が，この方向での二，三の試みについて紹介しておくこ とも, 将来のためには決して無駄にならないであろう。

\section{3 低温硬化型インキの考え方}

これはインキに含まれる成分の相互の反応によって乾 燥するタイプのインキである2)。このインキは容器の中 や印刷機上で反応してはならない。従来のブリキ印刷用 のインキや金属コーチング塗料のように反応を加熱に よって促進する熱反応型インキとは違って，常温で硬化 する能力のあるポリマーを印刷の直前に配合してインキ を作る考え方である。

機械的, 化学的性能のすぐれた最終インキ皮膜を得る 方法として次のような方法が考えられる。

エポキシ基がアミンや酸無水物と容易に反応すること を利用することが考えられる。アミンとしては揮発性で 腐食性の大きい低分子アミンが当初考えられたのである が，分子量の高いポリアミドが急速に開発されているの で将来への可能性が示唆されている。

イソシアナートは活性水素を有するアルコール, 酸, アミン, 水など多くの化合物と反応するので, 多官能性 イソシアナートとこのような多官能性化合物との反応に 
よって多種類の構造の異なるポリマーが容易に合成され る。多官能性物質としてはポリエステルまたはポリエー テルなどがある。問題はイソシアナートの方であって, 従来最も多く実用化されたのはトルイレンジイソシアナ 一ト (TDI) であるが，これは有毒で取扱が困難であ る。揮発性の少ない取扱の容易なものとしては適当なポ リイソシアナートの実用化をまたなければなるまい。

混合型インキを論ずる際にその一番大きい久点として 考えられることは二成分が別々の容器に分かれているこ とである。そこでこれを一体としたとき容器の中では安 定であるが，その成分相互の反応を印刷時あるいは印刷 後に促進させるようなくふうをこらさなければなるま い。たとえばインキが薄い皮膜の形で大気にさらされる とき，空気中や紙の水分と反応して橋力ケ皮膜を作るこ とが当然に考えられる。たとえば水分で硬化するポリウ レタンがある。イソシアナート基をもつ中程度の分子量 のポリマーを作れば，イソシアナート基が水と反応して 尿素結合ができる（ポリマーは最初ウレタン結合をもっ ているかもしれないが，生成した橋カケはウレタン結合 ではない)。この反応はまったく急速でアミンによって 促進することができる。しかし，その速度を制御するこ とは簡単ではない。とくに環境の変化しやすい場合はし かりである。これをインキの乾燥に応用するにしても印 刷時の安定性にはかなりの問題があり, 完成にはまだ遠 い道のりがあるように考えられる。

エポキシ樹脂については，大気中の水分で分解して硬 化剂を生成するような化合物を共用すれば，水分がうま く利用できよう。またプレッシュアセットインキのよう に印刷時の圧力のかかった瞬間にカプセルや毛細管の中 にはいっている触媒あるいは硬化剂がしぼりだされるよ うな形のインキを考えることも可能であるう。

しかし，これらの実現完成にはさらに多くの実験と時 間が必要であろう。

\section{4 新しい乾燥方式}

熱硬化型インキであれ，溶剤蒸発型インキであれ，印 刷後の乾燥方式が現在よりも進歩すれば，その忘用範囲 は遥かに拡大されることが考えられる。

現在は印刷インキはほとんど溶剤蒸発型であるから， 加熱と同時に強力な送風が主眼となった乾燥装置が開発 されているわけであるが，このような単に熱伝導方式に よらず，輻射エネルギーによって選択的に効率的に乾燥 する方法が考えられ，将来インキ，印刷機，乾燥装置を 一環とした一つのシステム化の努力が行なわれ始めてい る。

\section{$4 \cdot 1$ マイクロ波乾燥 ${ }^{3}$}

マイクロ波乾燥は電子レンジの原理を応用したもので ある。マイクロ波発生装置は $2,450 \mathrm{MHz}$ の電磁波を放
射するもので, 1967 年英国のエデンフィッシャーハー スト社が開発し，コンヴェントリーニュースペーパー社 で印刷機の巻取紙印刷の乾燥に初めて応用されたもので ある。

マイクロ波は可視光線のように一直線に進行し，物体 に反射，吸収されまた容易に透過する。したがってマイ クロ波は内部加熱を生じさせる効果がある。マイクロ波 加熱は，交番電界に扔かれた分子の運動による発熱を原 理としているから，極性の大きいものほど発熱しやす い。従来の乾燥方式では分子は熱源に近い表面から内部 一と順次熱せられていくし，また乾燥の初期に大量の熱 エネルギーが必要である。マイクロ波はマグネトロン発 振器によって発振され, 乾燥に必要なエネルギーとして $5 \mathrm{~kW}$ のマイクロ波エネルギーを供給する仕組みで運転 コストを減少させ，光沢のよいインキ皮膜を与え，また 紙の乾燥を少なくして表面の過熱を防ぐことができると いわれる。マイクロ波の熱転換率は照射される物質によ って異なり，極性の大きい分子をべースにしたものの方 が加熱効率がよい。したがって水性グラビアあるいはフ レキソインキあるいはグリコールなどをべースとした凸 版インキなどの乾燥にはとくに着目されてよい。しか し，オフセット印刷の場合は湿し水によって乳化される ことを嫌うために平版インキの成分はとくにハッ水性が 大きい（極性が小さい）のでマイク口波の応用は期待薄 であると考えるのが自然である。

設備費，運転費もさることながら，電波漏れの問題人 体に与える影響など充分に検討を加えることが必要であ ろう。

\section{$4 \cdot 2$ 赤外線乾燥}

赤外線は波長が $1 \sim 3 \mu$ であるが，これより長波長の 3〜20 $\mu$ の遠赤外線は印刷インキに対する吸収率もよ く，紙の温度もあげずに急速にインキ皮膜を乾燥させる 可能性をもつものと考えられ，とくに無溶剤の熱反応型 インキには適しているものと思われる。インキ皮膜の急 速な温度上昇が必要なときは熱伝導よりインキ自身の内 部発熱の方が効果的であると考えられるからである。

\section{$4 \cdot 3$ 紫外線乾燥 ${ }^{4}$}

従来発表されていた紫外線を照射して直ちに乾燥させ るタイプのインキは，キリ油や脱水ヒマシ油のような共 役二重結合を含む油性ワニスに，照射によって遊離の八 ロゲンあるいは発生機の酸素などを発生させるような有 機，無機の促進剤を加えたものをワニスとしたもので, 3,500 § あるいは 2,450 2,600 ̊ の波長帯を集中的に 照射すれば, 薄い皮膜ならば数秒で乾燥する型式のもの でわが国でも厚盛りのカルトン印刷などに一時使用され たことがあったが，残念ながら種々の欠陥があって一般 に普及するには至らなかった。

紫外線によって硬化する特殊な反応は製版関係に長い 
間利用されていた。触媒として重クロム酸カリウム, エ ネルギー源としてアーク燈を用いてゼラチンの皮膜を硬 化しているのは一つの例である。

最近はさらに光高分子化学の研究が進み, 数多い感光 性樹脂が開発され, 感光性樹脂凸版あるいはP S 版など として広く応用されるようになった。最近の紫外線硬化 インキはこのような新しい感光性樹脂を応用して発展し た点が従来型と異なっている。すなわちビヒクルは感光 性樹脂と光重合開始剤とから成り立っている。

紫外線乾燥は無溶剤であるとともに熱によって被印刷 物をいためない点, エネルギーコストから考えて従来の ヒートセットタイプより有利である。しかし, 紫外線エ ネルギーの透過能力は小さいので, 硬化速度は顔料, ビ ヒクルの透明度に支配されやすく, チタン白のような不 透明顔料を使用するインキに対しては効果が薄いが，色 インキは一般に透明度が高いので実用上充分である。

ビヒクルの機上印刷適性（安定性, 流動性) 適度の硬 化速度のコントロールによって, 版式, 被印刷材の種類 こかかわらず, 将来発展の予想されらるすぐれた乾燥シ ステムであると考えられる。

\section{$\mathbf{4 . 4}$ 電子線乾燥}

電子線の放射によって塗料を硬化する試みは 1966 年 こ米国で開発され，その後広範囲の実用研究が行なわれ ている。

電子線泣紫外線よりもエネルギ一強度が大きく, 急速 に硬化, 乾燥ができ，しかもエネルギーの透過性が高い から厚い不透明な塗膜でも乾燥できる。したがってチタ ン白のような不透明顔料を用いるブリキ印刷などのない ように紫外線硬化の考えられない場合には有効である。 またビヒクルは触媒や反応開始剤を必要としないから， 安定性がよいのも利点である。

しかし電子線放射器のコストが著しく高いこと, X線 やオゾンの発生などに対し充分保護することが必要であ り，通常の印刷物に対してはややコストの面から考えて オーバーな感じがしないでもない。

\section{5 水性グラビアインキ}

グラビアインキはその速乾性のゆえに出版, あるいは 新聞印刷用として独自の進歩を遂げているが，溶郕とし てガソリンあるいは類似の沸点のものを用いるが沛えに 暴発, 火災については何よりも留意しなければならない し, 事実都会地に扔いては消防法の規制がきわめて厳し くなってきている。また溶剤中に含まれた芳香族成分は 人体には有害であるから，換気を充分行ない，またイン キの取扱にも健康衛生上充分の配慮を行なわなければな らないし，また最近はとくに工場外に対する大気污染も 問題である。このような状況から大蔵省印刷局でも切手 印刷用として水性グラビアインキ使用の可能性が論ぜら
れ, 現実に実行段階に移っているし, 都会地におけるグ ラビア印刷工場でも逐次その使用に焦点があてられてい くことと思われる。

水性グラビアインキは顔料, 樹脂, アルコール, 水の 4 成分から成り立っており, 印刷後アルコールが蒸発す れば樹脂は顔料を包んだまま沈殿, 乾燥し, 乾燥後は充 分な耐水性, 耐溶剤性をもつようになる。樹脂は酸価の 充分に高いロジン変性マレイン酸樹脂, スチレン・アク リル酸共重合体などが用いられ，アンモニアアルカリ性 の状態で水に溶解する。アンモニアは蒸発しやすいの で, 揮発しにくい低級アミンを用いることもある。アル コールとしてイソプロパノールあるいは $n$-プロパノー ルなどの使用される場合が多い。

問題点としては使用する樹脂, アルコールのコストが 高いこと, 乾燥皮膜の光沢にそしいこと, 水の乾燥が遅 いことなどがあげられるが, 最近では皮膜の耐水性や光 沢も充分実用に耐えられるものができるようになった。 水のため, 紙の伸縮の問題があるが, これは適当な強制 乾燥によって解決が可能である。

\section{6 常温乾燥手段の進歩}

以上述べた各種のインキおよびその畭燥システムはい ずれにしても, 莫大な印刷設備 (巻取印刷機) 乾燥設備 などを具備する必要があるわけで，この負担に耐えられ るのは大企業だけである。とすれば, 零細な大多数の印 刷業者は速乾性, ノンオフセット（積み重ねた印刷紙上 のインキが裏移りしない）の福音を享受することができ ないのだろらか。中小印刷業者のもつ印刷設備は主とし て枚葉機であり, 要は一枚ずつ印刷された印刷紙を積み 重ねた場合裏移りせず, 後は本来の酸化, 重合を待って 完全乾燥をはかればよく，それには $1 \mathrm{sec}$ 内外の強制乾 燥などは必要でない。このため溶剤を一部選択的に紙に 吸収させるクイックセットタイプのインキで充分である が，さらに乾燥性の向上を称らったいろいろのインキが 別の見地から考えられているので, その一, 二を紹介し よう。

\section{1 水分散型インキ5}

モイスチュアセットからさらに進歩したタイプのイン キである。酸価の高いマレイン酸樹脂をグリコールに溶 解したものにある種のアミンが含まれている。印刷直後 インキが紙中に浸透し, 紙の酸性が有機アミンによって 中和される瞬間に樹脂が沈殿しセットするものと思われ る。もちろんインキは水溶性であるから, 通常のオフセ ットには適しないが, 凸版, ドライオフセット印刷の将 来には楽しみがある。

\section{2 可塑剂, 触媒の利用 ${ }^{6)}$}

速乾性のインキを望むにあたって長年懸案になってい た一つの手段として紙中に触媒を加えておき, 印刷直 
後, インキとの間に直ちに反応を進めさせようという考 えがあり, 事実過酸化物を紙中に加え遊離の酸素の存在 によって酸化を促進しょうといら試みが行なわれた。し かし，この考え方には市販されている紙がすべてそのよ らな処理が行なわれなければならないといら大きな障害 があり到底実行不能である。

インキビヒクルの主要成分は樹脂, 乾性油, 溶剤であ り, 樹脂はインキ皮膜にかたさと光沢を与え, 乾性油は 光沢を与えると同時にインキと被接着剤の接着剤として また可塑剤としての役目をする。溶剤は印刷面に浸透し てセットを早める。

最近英国では乾性油の一部をある種の可塑剤に置き換 えることによって, 光沢と接着力を増し, アフタータッ クを防ぐようなインキの開発につとめている ${ }^{6)}$ 。ビヒク ル製造段階において触媒が加えられるが，印刷後ビヒク ルは紙中に急速に浸透し, とくに紙中のチタン白, クレ 一などに強く吸着され, 紙との接着はきわめて強固なも のとなり，摩擦に対する抵抗のきわめて大きなインキ皮 膜となる。重合反応は 1 2 hr 以内に完了し, 光沢もよ いし乾燥後粘つきもない。

このインキの特徴は全面的に酸化のみに依存して乾燥 するわけでないが，印刷条件にあまり左右されることな く印刷できるのが特徴である。

\section{3 ノンオフセット凹版インキ}

著者の立場上ここで銀行券や郵便切手に用いられる凹 版印刷インキのことに触れておきたい, 四版印刷は文字 や線の凹みがある版面の全面にインキをつけて, これを しわ紙, 布, ローラーなどで拭き取ると凹みの部分だけ にインキが残るので, これに紙を当てて印刷する方式で ある。版の凹みは浅いところで数 $10 \mu$ 深いところで $200 \mu$ にも及ぶので, 通常は裏移りを防ぐために印刷一 枚ごとに間紙を入れる。これは世界各国ともは行なわれ ている事柄である。間紙を不要にすることは証券印刷技 術者の悲願であったが, 現在印刷局では全面的に成功を みている。

ヒートセット方式は印刷機の構造からも，上述の印刷 インキ皮膜の厚みから考えても不適当であったし, 何よ りもインキ皮膜の物理的, 化学的にもゼイ弱で, 証券用 としては適当なものが得られなかった。

スチームセットインキも極性の大きい樹脂からは必要 な化学的強度は期待できないし，とくにわが国のような 多湿国では機上安定性に乏しかった。

紫外線硬化型インキも試みられたが，薄い平版インキ
皮膜ならいざ知らず， $100 \mu$ 以上の凹版インキ皮膜では その効果はあまり上らなかったし，また照射時発生する 八ロゲン,オゾンなど有害ガスの処理, 紫外線もれなど で失敗に終った。

そこで一切の乾燥手段, 設備を用いることなくインキ の物理的性状のみを改良して裹移りしない四版インキの 開発に重点が向けられた。

印刷機上のローラーや版上ではインキは絶えず激しい ずりの力を受けるから, インキの内部構造が崩れて粘度 や降伏価が下がり，版や紙へのインキの転移がほどよい ものとなる。しかし, 紙に一たん印刷された後はこのよ らなインキの流動性はもはや無用の長物と化するばかり でなく, 裹移りを促進する重大な障害となる。つまりイ ンキ皮膜が分裂して紙に移り, 内部応力が緩和されると ともにできるだけ速く元の構造にもどって堅くなる,つ まりチキソトロピーの大きいことが望まれる。これは裹 移り防止といら立場ばかりでなく, 印刷画像の鮮鋭さを 保持する上からも重要である。インキのチキソトロピー を大きくするためには非晶質シリカ，アルミニウムセッ ケン, 有機アミン変性ベントナイト, チキソトロピック アルキド樹脂などの利用が有効である。

このほか, 印刷インキの皮膜表面とその上に重なる紙 の裏面の付着エネルギーを落とす目的から，凹版インキ 中にパラフィンロウ,ミツロウ, モンタンロウ, カーナバ ロウ，低分子量のポリエチレンなどを加えることによっ て, 印刷直後インキ皮膜表面に単分子層に近いワックス が浮かび上がって, 紙との付着エネルギーは一挙に $1 / 10$ 程度に落ち, 裹移り防止上相当な効果がある。

インキ製造にあたっては，あまりチキソトロピーを大 きくしたり，ワックスを大量に加えると印刷適性（イン キののび, 転移性など) が阻害される場合が多いので, 実際のインキ配合にあたっては慎重な配慮が必要であ る。

（昭和 47 年 4 月 21 日受理）

\section{文献}

1) H.C. Loret, Amer. Ink Maker, 47 (8), 24 26, 56 57 (1969)

2) A.R.H. Tawn, Brit. Ink Maker, 11 (1), 17 12 (1968)

3) Conventry Newspaper, Brit. Printer, 82 (9), 122 125 (1969)

4) D.J. Carlick, Amer. Ink Maker, 49 (12),20 22 (1971)

5) C. Bloy, Graphic Technology, No. 21, Jan. 20 24 (1967)

6) A.R. Gibbon, Brit. Printer, 85 (1), 53 (1972) 